\title{
Hypocretin/Orexin Innervation and Excitation of Identified Septohippocampal Cholinergic Neurons
}

\author{
Min Wu, ${ }^{1}$ Laszlo Zaborszky, ${ }^{5}$ Tibor Hajszan, ${ }^{4,5}$ Anthony N. van den Pol, ${ }^{2}$ and Meenakshi Alreja ${ }^{1,3}$ \\ Departments of ${ }^{1}$ Psychiatry, ${ }^{2}$ Neurosurgery, and ${ }^{3}$ Neurobiology, Yale University School of Medicine and the Ribicoff Research Facilities, Connecticut \\ Mental Health Center, New Haven, Connecticut 06508, ${ }^{4}$ Center of Molecular and Behavioral Neuroscience, Rutgers University, Newark, New Jersey 07102 , \\ and ${ }^{5}$ Laboratory of Molecular Neurobiology, Biological Research Center, Szeged, Hungary 6726
}

Hypothalamic fibers containing the wake-promoting peptides, hypocretins (Hcrts) or orexins, provide a dense innervation to the medial septum-diagonal band of Broca (MSDB), a sleep-associated brain region that has been suggested to show intense axonal degeneration in canine narcoleptics. The MSDB, via its cholinergic and GABAergic projections to the hippocampus, controls the hippocampal theta rhythm and associated learning and memory functions. Neurons of the MSDB express very high levels of the Hcrt receptor 2, which is mutated in canine narcoleptics. In the present study, we investigated the electrophysiological effects of Hcrt peptides on septohippocampal cholinergic neurons that were identified in living brain slices of the MSDB using a selective fluorescent marker. Hcrt activation of septohippocampal cholinergic neurons was reversible, reproducible, and concentration dependent and mediated via a direct postsynaptic mechanism. Both Hcrt1 and Hcrt2 activated septohippocampal cholinergic neurons with similar $\mathrm{EC}_{50}$ values. The Hcrt effect was dependent on external $\mathrm{Na}^{+}$, reduced by external $\mathrm{Ba}^{2+}$, and also reduced in recordings with CsCl-containing electrodes, suggesting a dual underlying ionic mechanism that involved inhibition of a ${ }^{+}$current, presumably an inward rectifier, and a $\mathrm{Na}^{+}$-dependent component. $\mathrm{The}^{+}{ }^{+}$component was dependent on internal $\mathrm{Ca}^{2+}$, blocked by replacing external $\mathrm{Na}^{+}$with $\mathrm{Li}^{+}$, and also blocked by bath-applied $\mathrm{Ni}^{2+}$ and KB-R7943, suggesting involvement of the $\mathrm{Na}^{+}-\mathrm{Ca}^{2+}$ exchanger. Using double-immunolabeling studies at light and ultrastructural levels, we also provide definitive evidence for a hypocretin innervation of cholinergic neurons. Thus Hcrt effects within the septum should increase hippocampal acetylcholine release and thereby promote hippocampal arousal.

Key words: theta rhythm; hypocretin; orexin; sleep; memory; cognition; acetylcholine; cataplexy; narcolepsy

\section{Introduction}

The wake-promoting peptides, hypocretins/orexins, have been implicated in normal sleep-wakefulness and in narcolepsy, a disorder characterized by rapid eye movement (REM) sleep dysregulation and an inability to maintain wakefulness (Mignot et al., 2002; Scammell, 2003). Thus, canine and human narcoleptics have an impaired hypocretin (Hcrt) system (Lin et al., 1999; Peyron et al., 2000; Thannickal et al., 2000). Hcrt peptide and Hcrtreceptor (Hcrt-R) knock-out mice are also narcoleptic (Chemelli et al., 1999, 2000; Hara et al., 2001; de Lecea et al., 2002; Willie et al., 2003). Hcrt neurons, which are located in the hypothalamus, innervate several sleep-associated brain regions that include the medial septum-diagonal band of Broca (MSDB) (de Lecea et al., 1998; Peyron et al., 1998; Nambu et al., 1999). The onset of symptoms in canine narcolepsy is accompanied by degenerative changes in forebrain regions, particularly the MSDB (Siegel et al., 1999).

\footnotetext{
Received July 30, 2003; revised Feb. 20, 2004; accepted Feb. 28, 2004

This work was supported by National Institutes of Health Grants MH61465 (M.A.), NS37788 (A.N.V.), and NS32945 (L.Z.). We thank N. Margiotta for technical assistance and Leslie Rosello for secretarial help.

Correspondence should be addressed to Meenakshi Alreja, Department of Psychiatry, Connecticut Mental Health Center 335A, Yale University School of Medicine, 34 Park Street, New Haven, CT 06508. E-mail: meenakshi.alreja@yale.edu.

D0I:10.1523/JNEUROSCI.5364-03.2004

Copyright $\odot 2004$ Society for Neuroscience $\quad 0270-6474 / 04 / 243527-10 \$ 15.00 / 0$
}

The MSDB has high levels of Hcrt-R2 mRNA and protein (Trivedi et al., 1998; Hervieu et al., 2001; Marcus et al., 2001; Cluderay et al., 2002; Wu et al., 2002), a receptor subtype that is specifically implicated in canine narcolepsy (Lin et al., 1999). In contrast, the MSDB has "low density slightly above background" levels of Hcrt-R1 mRNA (Marcus et al., 2001). The presence of Hcrt-R1 protein is debatable (Trivedi et al., 1998; Hervieu et al., 2001).

The MSDB sends cholinergic and GABAergic fibers to the hippocampus via the septohippocampal pathway and controls the hippocampal theta rhythm and associated mnemonic functions. Theta rhythm, which accompanies exploratory behavior and REM sleep, is suppressed by MSDB lesions (Vanderwolf, 1969; Winson, 1976). Pronounced hippocampal theta occurs during cataplectic attacks in canine narcoleptics (Kushida et al., 1985). REM sleep deficits also occur in neurodegenerative disorders associated with a loss of basal forebrain cholinergic neurons, such as Lewy body dementia and Alzheimer's disease (Vitiello and Prinz, 1989; Montplaisir et al., 1998).

Hcrt is excitatory to CNS neurons including those believed to be involved with arousal (Ivanov and Aston-Jones, 2000; Eggermann et al., 2001; Burlet et al., 2002; Korotkova et al., 2003). In a recent study we reported that septohippocampal GABAergic neurons are innervated by Hcrt-containing fibers, express Hcrt$\mathrm{R} 2$, and are excited by $\mathrm{Hcrts}$ via activation of the $\mathrm{Na}^{+}-\mathrm{Ca}^{2+}$ 
exchanger (Wu et al., 2002). In the same study, we also observed Hcrt-R2 immunoreactivity in non-GABAergic MSDB neurons.

Because the septohippocampal cholinergic neurons comprise the second major population of neurons in the MSDB, we hypothesized that cholinergic neurons may also be targeted by Hcrts. Light microscopy studies have demonstrated the presence of Hcrt terminals in cholinergic neuron-rich basal forebrain regions; the importance of these putative connections in regulating sleep-wakefulness has been heavily speculated on, and models have been created to explain their possible role in arousal (Kilduff and Peyron, 2000).

Therefore, in this study we used double-immunolabeling studies at light and electron microscopic levels to determine the relationship between Hcrt fibers and the septohippocampal cholinergic neurons. We also investigated the electrophysiological actions of Hcrt on identified septohippocampal cholinergic neurons using rat brain slices.

\section{Materials and Methods}

Labeling of septohippocampal cholinergic neurons using indocarbocyanine$192 \operatorname{IgG}$. Septohippocampal cholinergic neurons were identified in the living state using the fluorescent marker [indocarbocyanine (Су3)192IgG] as described previously (Alreja et al., 2000; Wu et al., 2000). This technique exploits the fact that septohippocampal cholinergic neurons, but not the GABAergic neurons of the MSDB, exclusively express the low-affinity nerve growth factor receptor, p75. Thus, Cy3-192IgG, which is a conjugate of the fluorochrome $\mathrm{Cy} 3$, and an antibody $(\mathrm{Ab})$ against the p75 receptor (192IgG), is taken up only by cholinergic terminals and thus selectively labels only the cholinergic subpopulation. The specificity of this marker and its inert nature have been thoroughly confirmed in previous studies by us (Alreja et al., 2000; Wu et al., 2000, 2003b) and by others (Hartig et al., 1998).

In anesthetized rats, Cy3-192IgG (3-5 $\mu \mathrm{l} ; 0.4 \mathrm{mg} / \mathrm{ml})$ was stereotaxically injected bilaterally into the lateral ventricle of each rat with a Hamilton syringe ( 22 gauge needle) at a rate of $0.5 \mu \mathrm{l} / \mathrm{min}$. The coordinates used were as follows: $0.8 \mathrm{~mm}$ posterior from bregma, $1.2 \mathrm{~mm}$ lateral from midline, and 3-4 $\mathrm{mm}$ below the dura. Slices were prepared 2-5 d later from Cy3-192IgG-injected rats and used for electrophysiological recordings.

Slice preparation for electrophysiological recordings. Brain slices containing the MSDB were prepared from Cy3-192IgG-injected male Sprague Dawley albino rats (2-4 weeks old) using methods detailed previously (Alreja and Liu, 1996). Briefly, rats were anesthetized with chloral hydrate ( $400 \mathrm{mg} / \mathrm{kg}$, i.p.) and killed by decapitation. The artificial CSF (ACSF), $\mathrm{pH} 7.35-7.38$, equilibrated with $95 \% \mathrm{O}_{2}-5 \% \mathrm{CO}_{2}$, contained (in mM): $128 \mathrm{NaCl}, 3 \mathrm{KCl}, 1.25 \mathrm{NaH}_{2} \mathrm{PO}_{4}, 10$ D-glucose, $26 \mathrm{NaHCO}_{3}, 2$ $\mathrm{CaCl}_{2}$, and $2 \mathrm{MgSO}_{4}$. After decapitation, brains were removed and placed in a Petri dish containing ACSF and trimmed to yield a small block containing the MSDB. From each brain, two coronal slices of $300 \mu \mathrm{m}$ thickness were obtained with a Vibratome 1500 (The Vibratome Company, St. Louis, MO) and transferred to a Plexiglas recording chamber ( $1.5 \mathrm{ml}$ volume) on the fixed stage of an Olympus BX50WI scope. The slices were maintained at $33 \pm 0.5^{\circ} \mathrm{C}$; the slice was used for recording $1-2$ $\mathrm{hr}$ later. The chamber was perfused continuously with normal ACSF at a rate of $2-3 \mathrm{ml} / \mathrm{min}$, and its temperature was maintained at $33 \pm 0.5^{\circ} \mathrm{C}$. Visualized whole-cell patch-clamp recordings on identified septohippocampal cholinergic neurons were performed using the infrared, differential interference contrast (IR-DIC) imaging setup (see below). To block synaptic transmission, a nominally $\mathrm{Ca}^{2+}$-free, high- $\mathrm{Mg}^{2+} \mathrm{ACSF}$ that had no added $\mathrm{Ca}^{2+}$ was used (in $\mathrm{mM}$ ): $128 \mathrm{NaCl}, 3 \mathrm{KCl}, 1.25$ $\mathrm{NaH}_{2} \mathrm{PO}_{4}, 10$ D-glucose, $26 \mathrm{NaHCO}_{3}, 0 \mathrm{CaCl}_{2}$, and $10 \mathrm{MgSO}_{4}$.

Ionic mechanism studies. Sodium replacement was done using Tris or $\mathrm{Li}^{+}$, because choline may be taken up by the cholinergic neurons. The composition of the Tris/ $/ \mathrm{Li}^{+}$ACSF was as follows (in mM): $128 \mathrm{Tris} / \mathrm{LiCl}$, $3 \mathrm{KCl}, 1.25 \mathrm{NaH}_{2} \mathrm{PO}_{4}, 10$ D-glucose, $26 \mathrm{NaHCO}_{3}, 2 \mathrm{CaCl}_{2}$, and $2 \mathrm{MgSO}_{4}$. A 100 mm stock solution of $\mathrm{BaCl}_{2}$ or $\mathrm{NiCl}_{2}$ was added to the ACSF to yield a final concentration of $300 \mu \mathrm{M}$ to $1 \mathrm{mM}$ for $\mathrm{BaCl}_{2}$ or $250 \mu \mathrm{M}$ to $3 \mathrm{~mm}$ for
$\mathrm{NiCl}_{2}$. Ionotropic glutamate receptor antagonists (50 $\mu \mathrm{M}$ AP-5 and 25 $\mu \mathrm{M} C N Q X)$ and $\mathrm{GABA}_{\mathrm{A}}$ receptor antagonists $(10-30 \mu \mathrm{M}$ bicuculline or gabazine) were added to these solutions.

Fluorescence and infrared imaging. IR-DIC imaging was performed to visualize neurons for patch-clamp recording using an Olympus Optical BX-50 microscope (Olympus, Tokyo, Japan) using methods described in previous studies (Alreja et al., 2000; Wu et al., 2000). Cy3-192IgGlabeled neurons were visualized using the appropriate fluorescence filter. A neuron viewed with infrared optics was considered to be the same as that viewed with fluorescence optics when the infrared image and the fluorescent image of the neuron had the same position and orientation with the DIC and fluorescence.

Whole-cell recordings from visualized septohippocampal cholinergic neurons. The image of the cells in the slice was displayed on a video monitor, and glass pipettes used for electrophysiological recordings were visually advanced through the slice to the surface of the cell from which recordings were made. Whole-cell patch-clamp recordings were performed using previously described methods (Alreja and Liu, 1996). In brief, lowresistance (2.5-3.5 $\mathrm{M} \Omega$ ) patch pipettes were filled with a solution containing (in $\mathrm{mM}$ ): $120 \mathrm{~K}$ methylsulfonate/ $\mathrm{KCl}, 10$ HEPES, 5 BAPTA $\mathrm{K}_{4}, 20$ sucrose, $2.38 \mathrm{CaCl}_{2}, 1 \mathrm{MgCl}_{2}, 1 \mathrm{~K}_{2} \mathrm{ATP}$, and $0.1 \mathrm{GTP}, \mathrm{pH} 7.32$ 7.35. The concentration of free $\mathrm{Ca}^{2+}$ in this solution was $97 \mathrm{nM}$, assuming an absolute affinity constant for BAPTA of $9.35 \times 10^{6} \mathrm{M}^{-1}$ (Tsien, 1980). The composition of the $\mathrm{CsCl}$ patch pipette solution was as follows: $120 \mathrm{CsCl}, 10$ HEPES, 5 BAPTA Cs 4 , 20 sucrose, $2.38 \mathrm{CaCl}_{2}, 1 \mathrm{MgCl}_{2}, 1$ $\mathrm{K}_{2} \mathrm{ATP}$, and $0.1 \mathrm{GTP}, \mathrm{pH} 7.32-7.35$. BAPTA was added to the patch pipette solution at a concentration of $10 \mathrm{~mm}$, similar to that used in published studies related to ionic mechanisms (Liu et al., 2002; Burdakov et al., 2003).

Data were acquired using an Axoclamp-2B and pClamp 9 (Axon Instruments, Foster City, CA). In current-clamp recordings, the output signal was filtered at $10 \mathrm{kHz}$, and spike data were acquired at a sampling frequency of $20 \mathrm{kHz}$. Voltage-clamp recordings were performed using the continuous single-electrode voltage-clamp mode, filtered at $3 \mathrm{kHz}$, and acquired at $10 \mathrm{kHz}$. Access resistance was between 6-10 $\mathrm{M} \Omega$; no compensation was done. All recordings were done with respect to an $\mathrm{Ag} / \mathrm{AgCl}$ electrode located near the outflow of the chamber. Whole-cell liquid junction potential measurements were calculated to be $\sim 11 \mathrm{mV}$ for our internal solutions, and membrane potentials were not corrected. The current and voltage signals were amplified and displayed on storage oscilloscopes and also recorded continuously on a chart recorder (Gould 2200).

Current-voltage plots ( $I-V$ curves) were obtained before and during drug application using slow ramps $(6 \mathrm{mV} / \mathrm{sec})$ to allow for attainment of steady-state conditions. The ramps were generated using pClamp software and filtered at $10 \mathrm{~Hz}$.

Animals and tissue processing for light microscopy. Male Sprague Dawley rats $(n=6$; Zivic Miller, Portersville, PA) weighing 275-300 gm were deeply anesthetized with urethane (25\% urethane in saline; Sigma, St. Louis; $0.55 \mathrm{ml} / 100 \mathrm{gm}$, i.p.) and perfused transcardially with $50 \mathrm{ml} \mathrm{PBS}$, pH 7.55-7.65, followed by a $100 \mathrm{ml}$ mixture of $4 \%$ acrolein (Acros Organics, Geel, Belgium) and 2\% paraformaldehyde (PFA), and finally with $200 \mathrm{ml}$ 2\% PFA alone. Subsequently, the brains were removed and postfixed in $4 \% \mathrm{PFA}$ at $4^{\circ} \mathrm{C}$ overnight. All fixatives mentioned above were diluted in PBS. Coronal Vibratome sections $(50 \mu \mathrm{m})$ were cut into four separate sets throughout the septum and collected in PBS. Different sets of sections from each brain were used for light and electron microscopic processing. In processing for light microscopy, the tissue was immunostained as described below, and then the sections were mounted on elvanol [0.3\% polyvinyl alcohol, 70,000 molecular weight (Sigma, St. Louis, $\mathrm{MO}$ ), $30 \mathrm{~mm}$ ammonium acetate, and $0.1 \%$ sodium azide], airdried, cleared in xylenes, coverslipped with DPX (Electron Microscopy Sciences, Fort Washington, PA), and analyzed under a Zeiss Axioskop light microscope equipped with a Zeiss AxioCam digital camera.

Immunohistochemical procedures. The simultaneous immunoperoxidase labeling of Hcrt and choline acetyltransferase (ChAT), the biosynthetic enzyme for acetylcholine, was performed according to our standard protocol (Hajszan and Zaborszky, 2002). Briefly, the tissue was incubated for $2 \mathrm{~d}$ at room temperature (RT) in a mixture of polyclonal rabbit anti-Hcrt (1:2000) and polyclonal sheep anti-ChAT (Chemicon, 
Temecula, CA; 1:20,000) dissolved in PBS containing 2\% normal rat serum (Jackson ImmunoResearch Laboratories, West Grove, PA) and $0.5 \%$ Triton $\mathrm{X}-100$. The Hcrt antiserum has been described previously (van den Pol et al., 1998). After rinsing in PBS, the sections were incubated in biotinylated goat anti-rabbit IgG (Vector Laboratories, Burlingame, CA; 1:500 in PBS containing 2\% normal rat serum and $0.5 \%$ Triton X-100; overnight at RT) followed by ABC Elite (Vector Laboratories; 1:500 in PBS; $2 \mathrm{hr}$ at RT). After a brief rinse in Tris-buffered saline, pH 7.60, Hcrt-immunoreactive (-ir) elements were visualized using a nickel-diaminobenzidine chromogen that revealed Hcrt fibers in black. The nickel-diaminobenzidine precipitate was then silver-gold intensified, as described previously (Liposits et al., 1984), to increase the contrast in electron density between Hcrt and cholinergic structures, but the thyoglycolic acid pretreatment was omitted from the original protocol.

The ChAT-positive structures were visualized by incubating the sections, already immunostained for Hcrt, in biotinylated donkey antisheep IgG (Jackson ImmunoResearch Laboratories; 1:500 in PBS containing $2 \%$ normal rat serum and $0.5 \%$ Triton X-100; overnight at RT) and in $\mathrm{ABC}$ Elite. To achieve appropriate visualization of the finest distal cholinergic dendrites, the tissue then went through the biotin-tyramide amplification procedure. After a brief rinse in PBS, the sections were reincubated in $\mathrm{ABC}$ Elite. Finally, the peroxidase reaction was performed using the diaminobenzidine chromogen that resulted in the light brown staining of ChAT-ir neurons.

To test for the possibility of cross-reaction between immunoreagents in the double-labeling experiments, separate series of sections were processed in the full immunohistochemical sequence with one or both primary antibodies replaced with nonimmune serum. Evidence of double labeling was not encountered in these control experiments.

Tissue processing for electron microscopy. The sections devoted to electron microscopic processing were double immunostained for Hcrt and ChAT as described above, although the preservation of ultrastructural details required the complete omission of Triton X-100 from all solutions. Instead, to enhance $\mathrm{Ab}$ penetration, the sections were incubated in $30 \%$ sucrose overnight at $4^{\circ} \mathrm{C}$ and freeze thawed sequentially three times in liquid nitrogen. In addition, incubations in primary and secondary antibodies were performed at $4^{\circ} \mathrm{C}$. After the immunohistochemical procedure, the sections were osmicated (1\% osmium tetroxide in PBS; 40 min), dehydrated in ethanol (the $70 \%$ ethanol contained $1 \%$ uranyl acetate; $40 \mathrm{~min}$ ), and flat embedded in Durcupan (Electron Microscopy Sciences) between liquid-release agent-coated slides and coverslips. Putative synaptic contacts were selected under the light microscope. The selection criteria are described in detail in the quantitative analysis section. The selected structures were photodocumented and re-embedded in Durcupan blocks. Ultrathin sections were cut on a Reichert Ultracut E ultramicrotome, collected on single-slot Formvar-coated grids, and examined in a Tecnai 12 transmission electron microscope equipped with a Gatan BioScan digital camera.

Quantitative analysis and digital imaging. By high-magnification light microscopic screening of both sides of the MSDB at a specific rostrocaudal level (bregma +0.40 ), ChAT cells were counted and sorted into two groups. ChAT neurons were sorted into the first group if they appeared to be contacted by Hcrt boutons according to the following criteria. ChAT cells were considered as targets of Hcrt-ir boutons if at least 1 Hcrt-ir varicosity was found in close apposition either to the cell body or to a dendrite being continuous with the perikaryon. Close appositions were defined as sites suggestive of synaptic input, i.e., side-to-side contacts with both the Hcrt bouton and the ChAT-ir profile being strictly in the same focal plane, with no discernible gap between the structures. ChAT cells that did not fulfill these criteria were sorted into the second group. Finally, the amount of ChAT-ir neurons contacted by Hcrt boutons (first group) was expressed as the percentage of all cholinergic cell bodies in the MSDB at the rostrocaudal level specified above (first group plus second group).

The quantitative analysis was performed from a group of three successfully processed brains. When necessary, contrast and lightness were adjusted on digital images. All pictures were assembled and lettering was added using the Adobe PhotoShop 5.5 software. The figures were printed with a Tektronix Phaser 740 color laser printer.
Drugs and drug application. The Hcrt2 peptide used was synthesized at Stanford University (Stanford, CA), and Hcrt1 was obtained from Phoenix Pharmaceuticals (Belmont, CA). $\mathrm{BaCl}_{2}(1 \mathrm{~mm}), \mathrm{NiCl}_{2}(3 \mathrm{~mm})$, and muscarine chloride were obtained from Sigma. Glutamate receptor antagonists ( $50 \mu \mathrm{M}$ AP-5 and $25 \mu \mathrm{M}$ CNQX) and GABA $_{\mathrm{A}}$ receptor antagonists (10-30 $\mu \mathrm{M}$ bicuculline or gabazine) were also obtained from Sigma. KB-R7943 (20-50 $\mu \mathrm{M})$ was obtained from Tocris Cookson (Ellisville, $\mathrm{MO})$. All drugs were diluted in ACSF from previously prepared stock solutions that were prepared in water and stored at $-20^{\circ} \mathrm{C}$. All antagonists and ion channel blockers were bath applied. Hypocretins and muscarine were applied using a Y-tube (Wu et al., 2003a).

\section{Results}

\section{Hcrts excite septohippocampal cholinergic neurons}

The effects of Hcrt peptides were tested on 200 septohippocampal cholinergic neurons that were selectively labeled using the fluorescent marker Cy3-192IgG (see Materials and Methods) (Fig. $1 a, b)$. All recorded neurons exhibited the electrophysiological signature that is characteristic of septohippocampal cholinergic neurons, which included presence of inward rectification but lack of a depolarizing sag in response to hyperpolarizing pulses (Griffith and Matthews, 1986; Markram and Segal, 1990; Gorelova and Reiner, 1996). Also, consistent with our published work, none of the 200 neurons recorded responded to muscarine with an excitation. This is in contrast to septohippocampal GABAergic neurons, which are excited by muscarine (Wu et al., 2000). Instead, $82 \%$ of the septohippocampal neurons recorded with $\mathrm{K}^{+}$containing electrodes were inhibited by muscarine $(37 \pm 2.7 \mathrm{pA}$ outward current; 141 of 176 cells tested), and the remaining neurons were not affected. As expected, none of the 24 cells recorded with CsCl-containing electrodes were inhibited by muscarine because internal $\mathrm{Cs}^{+}$blocks the $\mathrm{K}^{+}$channel-mediated inhibitory response in septohippocampal cholinergic neurons.

In the current-clamp mode, Hcrt2 produced a $7.5 \pm 1.4 \mathrm{mV}$ depolarization in the 16 septohippocampal cholinergic neurons tested using $\mathrm{K}$ methylsulfonate-containing electrodes (Fig. 1c). The Hcrt2-induced depolarization persisted in the presence of TTX in the five cells tested (control: $9.2 \pm 1.5 \mathrm{mV}$; TTX: $9.6 \pm 1.4$ $\mathrm{mV}$; Student's paired $t$ test; not significant) (Fig. $1 c, d$ ).

In voltage-clamp recording with $\mathrm{K}$ methylsulfonatecontaining electrodes as well as with $\mathrm{KCl}$-containing electrodes $(n=10)$, the excitatory effect of $1 \mu \mathrm{M}$ Hcrt was observed as an inward current (holding potential: $-65 \mathrm{mV}$ ) in $90 \%$ of the septohippocampal cholinergic neurons tested (mean: $-72.8 \pm 4.5$ $\mathrm{pA} ; n=138)($ Fig. $1 e, g, i)$.

Similar to the depolarization, the Hcrt-induced inward current also persisted in TTX in the five neurons tested (control: $-76 \pm 22 \mathrm{pA}$; TTX: $-64 \pm 20 \mathrm{pA}$; Student's paired $t$ test: no significant difference between control current and current in TTX) as well as in $\mathrm{Ca}^{2+}$-free, high $\mathrm{Mg}^{2+}$-containing ACSF (control: $-56.7 \pm 20.3 \mathrm{pA}$; $\mathrm{Ca}^{2+}$ free: $-40 \pm 20.8 \mathrm{pA} ; n=5$; Student's paired $t$ test between the two groups; not significant) (Fig. $1 d, e)$. Hcrt also induced responses of similar magnitude in both the absence and presence of $\mathrm{GABA}_{\mathrm{A}}$ and AMPA-kainate receptor antagonists (control: $-55 \pm 12.6 \mathrm{pA}$; after antagonists: $-47.5 \pm$ $11 \mathrm{pA} ; n=5$; data not shown; Student's paired $t$ test between the two groups; not significant).

In the 10 neurons tested, the magnitude of the response to a 1 $\mu \mathrm{M}$ concentration of Hcrt1 and Hcrt2 peptides was not significantly different (Hcrt1: $-77 \pm 13.2 \mathrm{pA}$; Hcrt2: $-83 \pm 14.2 \mathrm{pA}$ ) (Fig. $1 g, h$ ). Although Hcrt1 has a higher affinity for the Hcrt-R1 as compared with Hcrt2, both peptides have a similar affinity for the Hcrt-R2 (Sakurai et al., 1998). We therefore compared the $\mathrm{EC}_{50}$ values for the two peptides by plotting seven-point concen- 
a

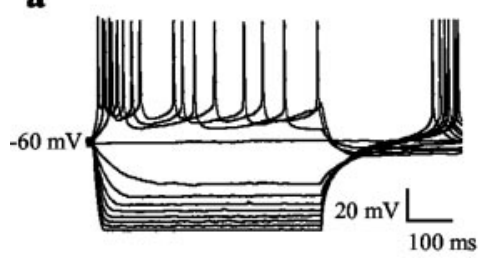

b
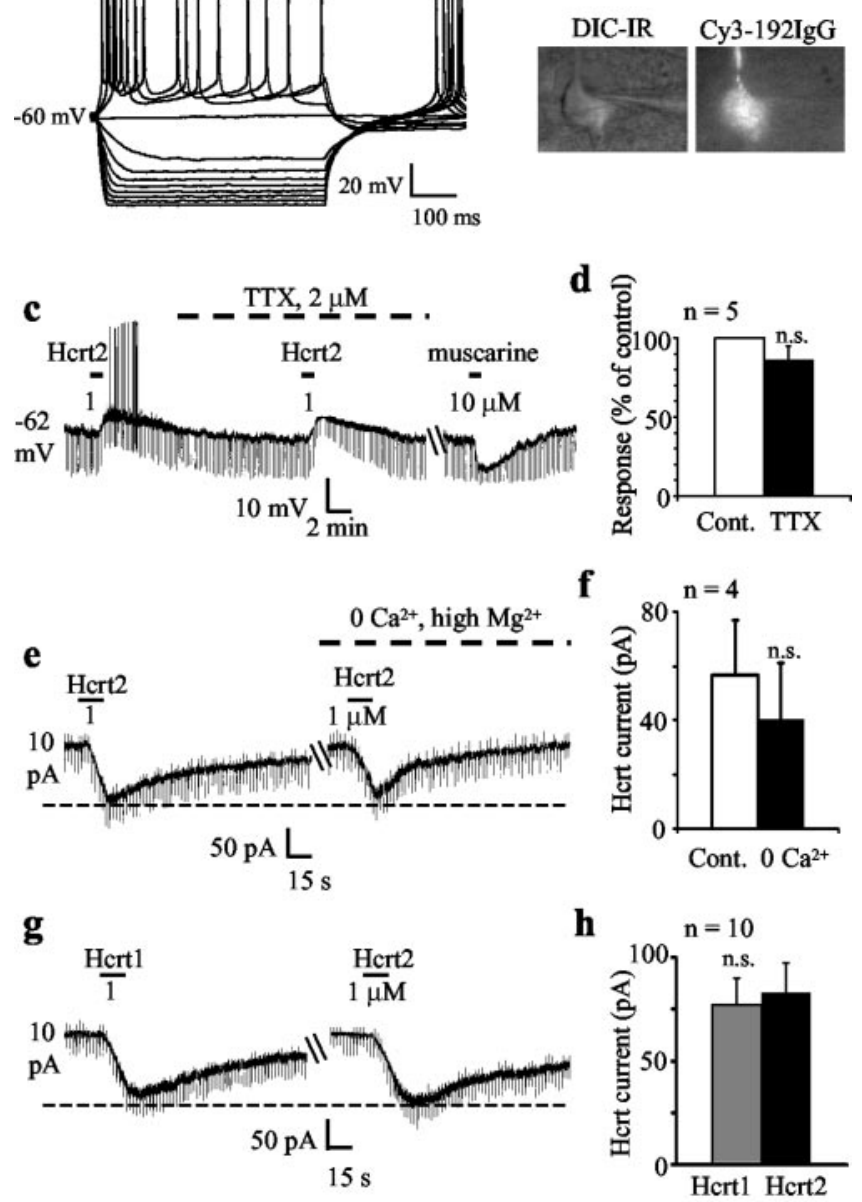

i

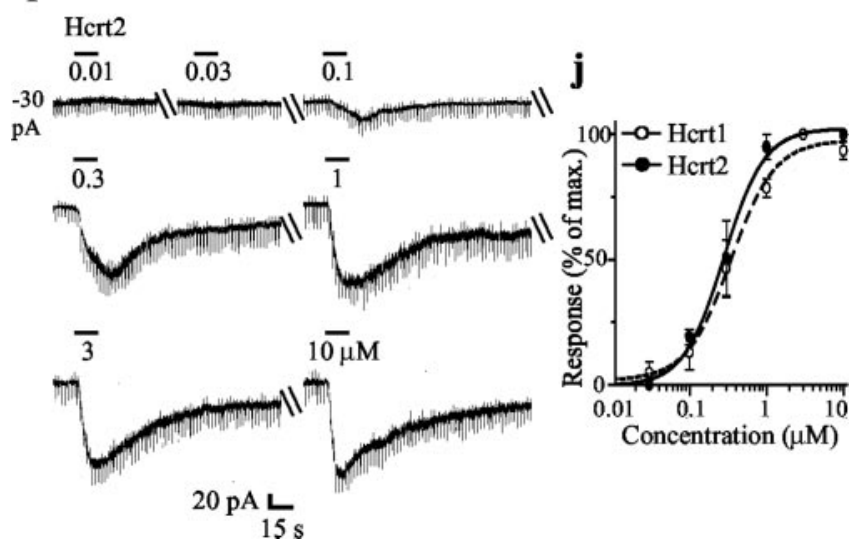

Figure 1. Septohippocampal cholinergic neurons are excited by the Hcrt peptides in a reversible, reproducible, concentration-dependent, and direct postsynaptic manner. $a, b$, Wholecell current-clamp recording shows a typical electrophysiological signature of a Cy3-192lgGlabeled septohippocampal cholinergic neuron. IR-DIC image is also shown. c, Current-clamp recording shows the depolarizing effect of Hcrt on a septohippocampal cholinergic neuron. Note the clear-cut decrease in input resistance; this decrease occurred in $10 \%$ of recorded neurons. The Hcrt-induced depolarization persisted in the presence of TTX. The cell responded to muscarine with a hyperpolarization. Unlike septohippocampal GABAergic neurons, cholinergic neurons are either inhibited or not affected by muscarine. $d$, Bar chart summarizes the effect of TTX on the Hcrt response in septohippocampal cholinergic neurons. $e, f$, Voltage-clamp recording (holding potential: $-65 \mathrm{mV}$ ) in which Hcrt2 induced an inward current that persisted in $\mathrm{Ca}^{2+}$ free-high-Mg ${ }^{2+}$-containing ACSF. Note the lack of a significant change in input conductance (as measured between -65 and $-70 \mathrm{mV}$ ); this was observed in a vast majority of neurons. Bar chart summarizes the data obtained from four cells. $g$, $h$, Similar response of a septohippocampal cholinergic neuron to equimolar concentrations of Hcrt1 and Hcrt2 peptides is shown. Note tration-response curves ( $10 \mathrm{~nm}$ to $10 \mu \mathrm{M}$ ) in three cells each. $\mathrm{EC}_{50}$ values of 345 and $280 \mathrm{~nm}$ were obtained for the Hcrt1 and Hcrt2 peptides, respectively (Fig. 1i,j).

\section{Ionic mechanism(s) of the Hcrt effect in septohippocampal cholinergic neurons}

To determine the ionic mechanism(s) underlying the Hcrtinduced excitation, $I-V$ curves in response to Hcrt were examined in conjunction with ion-substitution studies or in the presence of ion-channel blockers. Hcrt-induced excitatory responses in CNS neurons are mediated primarily via $\mathrm{Na}^{+}$-dependent mechanisms that include activation of the $\mathrm{Na}^{+}-\mathrm{Ca}^{+}$exchanger (Eriksson et al., 2001; Wu et al., 2002; Korotkova et al., 2003) or the nonselective cationic current (Brown et al., 2002; Liu et al., 2002; Yang and Ferguson, 2002; van den Top et al., 2003). Hcrt has also been reported to close $\mathrm{K}^{+}$channels (Ivanov and AstonJones, 2000; Hoang et al., 2003; van den Top et al., 2003).

$I-V$ curves for the Hcrt-induced response were recorded in a total of 30 neurons with $\mathrm{K}^{+}$-containing electrodes. Hcrt2 induced an inward current in the entire -65 to $-125 \mathrm{mV}$ range in 28 of 30 neurons tested, with no consistent change in input conductance as measured near $-65 \mathrm{mV}$; however, 3 of 30 cells recorded showed a significant increase in input conductance (Fig. $1 c)$, possibly attributable to a different underlying ionic mechanism. In $60 \%$ of these neurons, the Hcrt-induced inward current was larger at the more hyperpolarized potential of $-125 \mathrm{mV}$ (i.e., negative to the calculated $E_{\mathrm{k}}$ of $-103 \mathrm{mV}$ ) as compared with -65 $\mathrm{mV}$ (Fig. 2a1), and in $20 \%$ of neurons the Hcrt-induced inward current had a lower amplitude at $-125 \mathrm{mV}$ as compared with $-65 \mathrm{mV}$ (Fig. 2a2). In 13.3\% of neurons, the Hcrt-induced inward current was similar in magnitude at -65 and $-125 \mathrm{mV}$ (Fig. 2a3). In 2 of 30 neurons tested, the Hcrt2 induced an inward current that reversed near the calculated $E_{\mathrm{K}}$ of $-103 \mathrm{mV}$ (Fig. $2 a 4$ ), suggesting possible involvement of $\mathrm{K}^{+}$channels.

Because in a vast majority of septohippocampal cholinergic neurons the Hcrt-induced current was inward between -65 and $-125 \mathrm{mV}$, we first tested the effect of replacing $80 \%$ of the external $\mathrm{Na}^{+}$with Tris, an approach that is used by most studies investigating ionic mechanisms (Brown et al., 2002; Liu et al., 2002) because $100 \% \mathrm{Na}^{+}$replacement can alter neurotransmitter uptake and release (Parsons et al., 1992; Shen and North, 1992). Replacement of external $\mathrm{Na}^{+}$with Tris significantly reduced but did not block the Hcrt-induced inward current (at $-65 \mathrm{mV}$, control: $-76.7 \pm 10.8 \mathrm{pA}$; low $\mathrm{Na}^{+}:-20.5 \pm 4.3 \mathrm{pA}$; $p=0.0005 ; n=9)$ and also produced $I-V$ curves that tended to converge close to $E_{\mathrm{K}}$ or even cross at $E_{\mathrm{K}}$, possibly because of involvement of a $\mathrm{K}^{+}$conductance (Fig. $2 b, d$ ). To test for the presence of a $\mathrm{K}^{+}$component, we tested the effect of external $\mathrm{BaCl}_{2}$. It should be mentioned that in addition to blocking $\mathrm{K}^{+}$ channels, external $\mathrm{BaCl}_{2}$ can also alter responses mediated via nonselective cationic currents (Haj-Dahmane and Andrade, 1996). In the present study, bath application of $\mathrm{BaCl}_{2}(1 \mathrm{~mm})$ blocked inward rectification and reversibly altered the $I-V$ relationship of the Hcrt response in septohippocampal cholinergic neurons, producing $I-V$ curves that clearly diverged at hyper-

$\leftarrow$

that both peptides induced responses of a similar magnitude, suggesting possible involvement of Hcrt-R2. Bar chart summarizes the data from 10 cells. $i$, Response of a septohippocampal cholinergic neuron to increasing concentrations of $\mathrm{Hcrt} 2 . j$, Concentration-response curves for Hcrt1 and Hcrt2 show mean $\mathrm{EC}_{50}$ values of 345 and $280 \mathrm{~nm}$, respectively $(n=3$ for each peptide). 

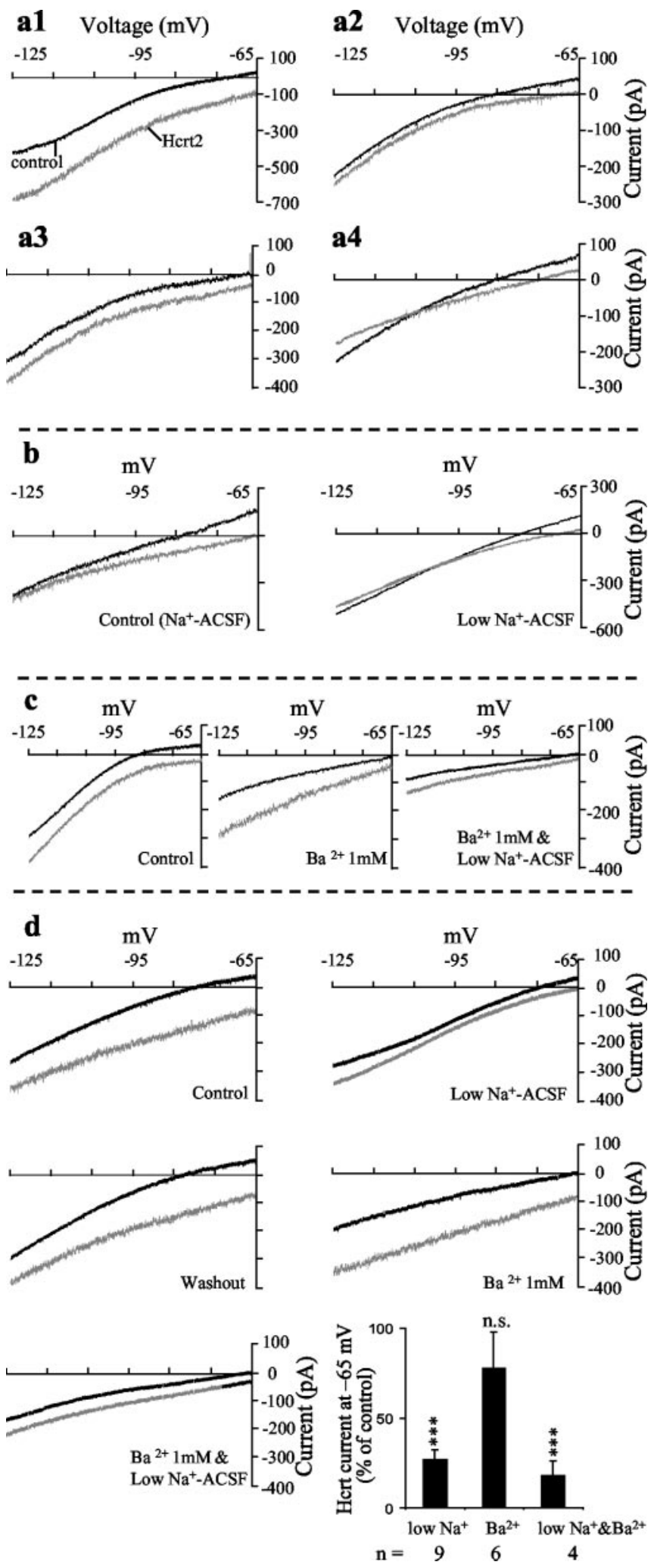

Figure 2. Dual $\mathrm{Na}^{+}$- and $\mathrm{K}^{+}$-dependent ionic mechanisms mediate the effects of Hort in septohippocampal cholinergic neurons. Voltage-clamp recordings from septohippocampal cholinergic neurons show the response of the cells to a slow ramp in the absence and presence of $\mathrm{Hcrt}$ recording using a $\mathrm{K}^{+}$-based pipette solution. a1-a4, Different type of $I-V$ curves obtained in septohippocampal cholinergic neurons in response to Hcrt. a1, This I-V relationship was observed in $60 \%$ of these neurons tested; the Hcrt-induced inward current was larger at the more hyperpolarized potential of $-125 \mathrm{mV}$ (i.e., negative to the calculated $E_{\mathrm{k}}$ of $-103 \mathrm{mV}$ ) as compared with $-65 \mathrm{mV} .92$, In $20 \%$ of neurons, the Hcrt-induced inward current had a lower amplitude at $-125 \mathrm{mV}$ as compared with $-65 \mathrm{mV}$. a3, In $13 \%$ of neurons tested the Hcrt- polarizing potentials (Fig. $2 c-e$ ). Thus, $\mathrm{BaCl}_{2}$ slightly reduced the Hcrt-induced inward current at $-65 \mathrm{mV}$ (control: $-54 \pm 5 \mathrm{pA}$; $\mathrm{BaCl}_{2}:-46 \pm 6.7 \mathrm{pA}$; not significant; $n=5$ ) but significantly enhanced it at potentials negative to the calculated $E_{\mathrm{k}}$ value of $-103 \mathrm{mV}$ (at $-125 \mathrm{mV}$; control: $-40.7 \pm 10.5 \mathrm{pA} ; \mathrm{BaCl}_{2}$ : $-87.8 \pm 16.8 \mathrm{pA} ; p=0.007 ; n=5$ ). Thus, the effect of $\mathrm{Ba}^{2+}$ was inconsistent with that of a nonselective cationic current because these currents are reduced by external $\mathrm{Ba}^{2+}$ throughout the voltage range tested (Mubagwa et al., 1997). Furthermore, addition of $\mathrm{Ba}^{2+}$ to the Tris ACSF reduced the Hcrt inward current in the entire voltage range tested (Fig. $2 c-e$ ), more than either treatment alone (at $-65 \mathrm{mV}$; control: $-82.5 \pm 22.5 \mathrm{pA} ; \mathrm{BaCl}_{2}$ in low- $\mathrm{Na}^{+}$ ACSF: $-15 \pm 6.4 \mathrm{pA} ; p=0.03 ; n=4)$.

To further test for the involvement of dual ionic mechanisms, we used $\mathrm{CsCl}$-containing patch electrodes because $\mathrm{Cs}^{+}$does not permeate through $\mathrm{K}^{+}$channels but can permeate through nonselective cationic channels with the same ease as $\mathrm{K}^{+}$. Also unlike $\mathrm{Ba}^{2+}$, internal $\mathrm{Cs}^{+}$does not block Hcrt or other neurotransmitter-induced activation of nonselective cationic channels (Farkas et al., 1996; Liu et al., 2002); internal Cs ${ }^{+}$also does not modify the activity of the $\mathrm{Na}^{+}-\mathrm{Ca}^{2+}$ exchanger (Keele et al., 1997). In recordings with $\mathrm{CsCl}$-containing patch electrodes, Hcrt induced an inward current in the entire -65 to -125 $\mathrm{mV}$ range, albeit of lower magnitude $\left(\mathrm{Cs}^{+}\right.$-containing electrode: $-53.8 \pm 7.9 \mathrm{pA} ; n=24 ; \mathrm{K}^{+}$-containing electrode: $-72.8 \pm 4.5$ $\mathrm{pA} ; n=138 ; p=0.058)$. In addition, in recordings with CsClcontaining electrodes, the $I-V$ curves did not show any convergence in the hyperpolarized direction, possibly because of blockade of the $\mathrm{K}^{+}$component (Fig. $3 a-c$ ).

The ionic nature of the $\mathrm{Na}^{+}$-dependent component of the Hcrt response was further examined using $\mathrm{CsCl}$ electrodes to isolate the $\mathrm{Na}^{+}$-dependent component. We first examined the effect of replacing external $\mathrm{Na}^{+}$with $\mathrm{Li}^{+}$, because similar to Tris, $\mathrm{Li}^{+}$cannot substitute for $\mathrm{Na}^{+}$in the $\mathrm{Na}^{+}-\mathrm{Ca}^{2+}$ exchange mechanism. $\mathrm{Li}^{+}$can substitute, however, for $\mathrm{Na}^{+}$as a charge carrier for the nonselective cationic channel (Lee and Boden, 1997) and the $\mathrm{Ca}^{2+}$-activated nonselective cation (CAN) channel (Yellen, 1982; Kimura et al., 1987; Crepel et al., 1994; Cho et al., 2003). An $80 \%$ substitution of external sodium with $\mathrm{LiCl}$ completely and reversibly abolished the response to $\mathrm{Hcrt}$ in all five neurons tested (at $-65 \mathrm{mV}$, control: $-72 \pm 18.2 \mathrm{pA} ; \mathrm{Li}^{+}$ACSF: $0 \pm 0 \mathrm{pA} ; p=$ $0.008 ; n=5$ ) (Fig. $3 a, b, i) . \mathrm{Li}^{+}$ACSF by itself also produced a reversible inward current $(-190 \pm 47 \mathrm{pA} ; n=5)$. Next, we tested the effects of external $\mathrm{Ni}^{2+}$, which is a nonselective blocker of the $\mathrm{Na}^{+}-\mathrm{Ca}^{2+}$ exchanger. Low concentrations of $\mathrm{NiCl}_{2}(250 \mu \mathrm{M})$,

induced inward current was similar in magnitude at -65 and $-125 \mathrm{mV} .04, \ln 7 \%$ of neurons tested the Hcrt2-induced inward current reversed near the calculated $E_{\mathrm{K}}$ of $-103 \mathrm{mV}$ (a4), suggesting the possible involvement of ${ }^{+}$channels. $b$, Hcrt response was reduced in low $\mathrm{Na}^{+}$-containing ACSF. In the example shown, the remaining response reversed close to the calculated $E_{\mathrm{K}}$ of $-103 \mathrm{mV}$, suggesting the presence of a $\mathrm{Na}^{+}$-dependent and a $\mathrm{K}^{+}$component. c, Application of $\mathrm{BaCl}_{2}$ blocked inward rectification and reduced the $H\left(c r\right.$ response at $-65 \mathrm{mV}$ but enhanced it negative to $E_{\mathrm{K}}$, presumably by blocking the effect of $\mathrm{Hcrt}$ on an inward rectifier $\mathrm{K}^{+}$current. Replacement of external $\mathrm{Na}^{+}$with Tris, in the presence of $\mathrm{BaCl}_{2}$, further reduced the response to $\mathrm{Hcrt}$ in the entire voltage range tested, suggesting the presence of two separate ionic mechanisms. $d$, Recording from another septohippocampal cholinergic neuron again shows the reduction in the Hcrt response in low $\mathrm{Na}^{+}$ ACSF. In this example, however, the remaining response reduced but did not reverse near $E_{\mathrm{K}}$. After return to normal $\mathrm{Na}^{+} \mathrm{ACSF}$, application of $\mathrm{BaCl}_{2}$ blocked inward rectification and reduced the Hcrt response at $-65 \mathrm{mV}$ but enhanced it negative to $E_{K}$, presumably by blocking the effect of $\mathrm{Hcrt}$ on an inward rectifier $\mathrm{K}^{+}$current. Replacement of external $\mathrm{Na}^{+}$with Tris, in the presence of $\mathrm{BaCl}_{2}$, further reduced the response to $\mathrm{Hcr}$ in the entire voltage range tested.e, Bar chart summarizes the presented evidence for involvement of dual ionicmechanisms. Mean current values shown are those recorded at $-65 \mathrm{mV}$. 

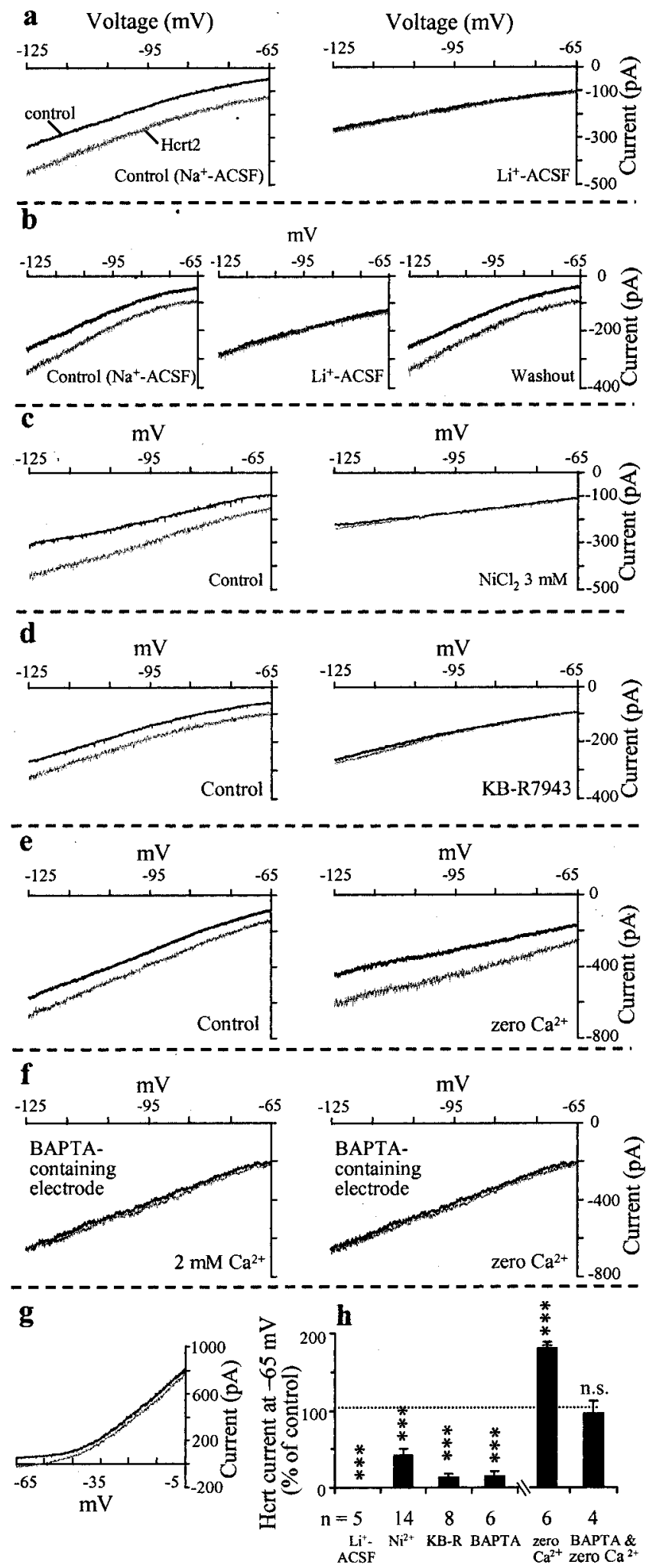

Figure 3. The $\mathrm{Na}^{+}$-dependent component of the Hcrt response in septohippocampal cholinergic neurons involves activation of the $\mathrm{Na}^{+}-\mathrm{Ca}^{2+}$ exchanger. Voltage-clamp recordings from septohippocampal cholinergic neurons show $I-V$ curves recorded in the absence and presence of $\mathrm{Hcrt}$ under different experimental conditions. All recordings were performed using $\mathrm{CsCl}$-containing patch electrodes to block the $\mathrm{K}^{+}$component and isolate the $\mathrm{Na}^{+}$-dependent component. $a, b$, Hcrt induces an inward current between -65 and $-125 \mathrm{mV}$ in the regular $\mathrm{Na}^{+}$-containing ACSF. The Hcrt response, however, is reversibly blocked in ACSF, where $80 \%$ of $\mathrm{Na}^{+}$has been replaced with $\mathrm{Li}^{+}$. $C$, Addition of $3 \mathrm{~mm} \mathrm{Ni}^{+}$to the regular $\mathrm{Na}^{+}$-containing ACSF also blocks the Hcrt response. $d$, KB-R7943 $(20 \mu \mathrm{M})$, a selective inhibitor of the $\mathrm{Na}^{+}{ }_{-} \mathrm{Ca}^{+}$ which block T-type but not high-voltage-activated $\mathrm{Ca}^{2+}$ channels or the $\mathrm{Na}^{+}-\mathrm{Ca}^{2+}$ exchanger, had no effect on the Hcrt response ( $n=3$; data not shown). In contrast, $3 \mathrm{mM} \mathrm{NiCl}_{2}$, which blocks the $\mathrm{Na}^{+}-\mathrm{Ca}^{2+}$ exchanger, significantly and reversibly reduced the Hcrt-induced inward current in septohippocampal cholinergic neurons (at $-65 \mathrm{mV}$, control: $-86.4 \pm 11.4 \mathrm{pA}$; $\mathrm{Ni}^{2+}:-36.4 \pm 7.3 \mathrm{pA} ; p=0.0005 ; n=14$ ) (Fig. $3 c, i$ ).

Furthermore, KB-R7943 (20-50 $\mu \mathrm{M})$, a blocker of the forward mode of the $\mathrm{Na}^{+}-\mathrm{Ca}^{2+}$ exchanger, significantly blocked the Hcrt-induced inward current (at $-65 \mathrm{mV}$, control: $-55 \pm 12.8$ pA; KB-R7943: $-7.5 \pm 2.5$ pA; $p=0.005 ; n=8$ ) (Fig. $3 d, i$ ).

Consistent with the involvement of the $\mathrm{Na}^{+}-\mathrm{Ca}^{2+}$ exchanger, removal of extracellular $\mathrm{Ca}^{2+}$ in the presence of normal $\mathrm{Mg}^{2+}$ enhanced the response to Hcrt (at $-65 \mathrm{mV}$, control: $-66.7 \pm 23.3 \mathrm{pA} ;$ no added $\mathrm{Ca}^{2+}:-118.3 \pm 41.4 ; p=0.005 ; n=$ 6) (Fig. 3e,h).

To further test for the involvement of the $\mathrm{Na}^{+}-\mathrm{Ca}^{2+}$ exchanger, we added the fast-acting $\mathrm{Ca}^{2+}$ buffer, BAPTA (10 mM), to the $\mathrm{CsCl}$ pipette solution to buffer the internal $\mathrm{Ca}^{2+}$. Although buffering internal $\mathrm{Ca}^{2+}$ does not alter Hcrt and other neurotransmitter activated-nonselective cationic current (Farkas et al., 1996; Shao and Feldman, 2000; Liu et al., 2002), it prevents activation of the $\mathrm{Na}^{+}-\mathrm{Ca}^{2+}$ exchanger. In the six septohippocampal cholinergic neurons tested, Hcrt failed to produce an inward current in the presence of internal BAPTA (Fig. $3 f, h$ ). In three cells, in which an Hcrt response was recorded immediately after establishment of whole-cell recording, a progressive decline in the amplitude of the inward current could also be observed, presumably caused by diffusion of BAPTA (data not shown).

Furthermore, Hcrt failed to induce an inward current, even after removal of extracellular $\mathrm{Ca}^{2+}$ in the four cells recorded with $10 \mathrm{~mm}$ BAPTA-containing patch electrodes (at $-65 \mathrm{mV}$, control: $-12.5 \pm 7.5 \mathrm{pA}$; no added $\mathrm{Ca}^{2+}:-12 \pm 8.9 \mathrm{pA}$; not significant; $n=4$ ) (Fig. $3 f, h$ ). This confirmed that the increase in Hcrt current observed in ACSF with no added $\mathrm{Ca}^{2+}$ is indeed caused by activation of the $\mathrm{Na}^{+}-\mathrm{Ca}^{2+}$ exchanger and not by some other ionic mechanism such as an increase in a nonselective cationic current.

We next performed depolarizing $I-V$ curves up to $-5 \mathrm{mV}$ in the absence and presence of Hcrt. As expected from the calculated reversal potential for the $\mathrm{Na}^{+}-\mathrm{Ca}^{2+}$ exchanger, an inward current was obtained in the entire voltage range in the three cells tested (Fig. $3 g$ ). The expected reversal potential is $+195 \mathrm{mV}$ under our resting conditions $\left(\left[\mathrm{Na}^{+}\right]_{\mathrm{o}}=154 \mathrm{mM},\left[\mathrm{Na}^{+}\right]_{\mathrm{i}}=1 \mathrm{mM}\right.$, $\left.\left[\mathrm{Ca}^{2+}\right]_{\mathrm{o}}=2.38 \mathrm{~mm},\left[\mathrm{Ca}^{2+}\right]_{\mathrm{i}}=97 \mathrm{nM}\right)$ as calculated for a $3: 1$ stoichiometry of the $\mathrm{Na}^{+}-\mathrm{Ca}^{2+}$ exchanger using the equation $E_{\mathrm{Na}-\mathrm{Ca}}=3 E_{\mathrm{Na}}-2 E_{\mathrm{Ca}}$ (Kimura et al., 1987; Ehara et al., 1989;

exchanger, also blocked the Hcrt-induced inward current in the entire voltage range tested. $e_{\text {, }}$ As expected for the $\mathrm{Na}^{+}-\mathrm{Ca}^{2+}$ exchanger, Hcrt response is increased at all potentials in ACSF with no added $\mathrm{Ca}^{2+}$ ("zero" $\left.\mathrm{Ca}^{2+}\right) . f$, Hcrt failed to induce an inward current in neurons recorded with patch electrodes containing the fast-acting $\mathrm{Ca}^{2+}$ buffer BAPTA $(10 \mathrm{~mm})$, both in normal $\mathrm{Ca}^{2+}$-containing and in zero $\mathrm{Ca}^{2+}$-containing ACSF. Thus, the increase in Hcrt current that is normally observed in zero $\mathrm{Ca}^{2+}$ ACSF is also BAPTA sensitive and not caused by recruitment of a BAPTA-insensitive mechanism, such as a nonselective cationic current. $g$, Depolarizing ramps from -65 to $-5 \mathrm{mV}$ show that $\mathrm{Hcrt}$ induces an inward current in the entire voltage range, as would be expected from the calculated reversal potential of the $\mathrm{Na}^{+}-\mathrm{Ca}^{2+}$ exchanger but not a nonselective cationic current (see Results). $h$, Bar chart summarizes the effect of the above treatments on the Hcrt-induced inward current in septohippocampal cholinergic neurons. Thus, the $\mathrm{Na}^{+}$-dependent component of the Hcrt-induced inward current in septohippocampal cholinergic neurons requires internal $\mathrm{Ca}^{2+}$ and is mediated via activation of the $\mathrm{Na}^{+}-\mathrm{Ca}^{2+}$ exchanger. 


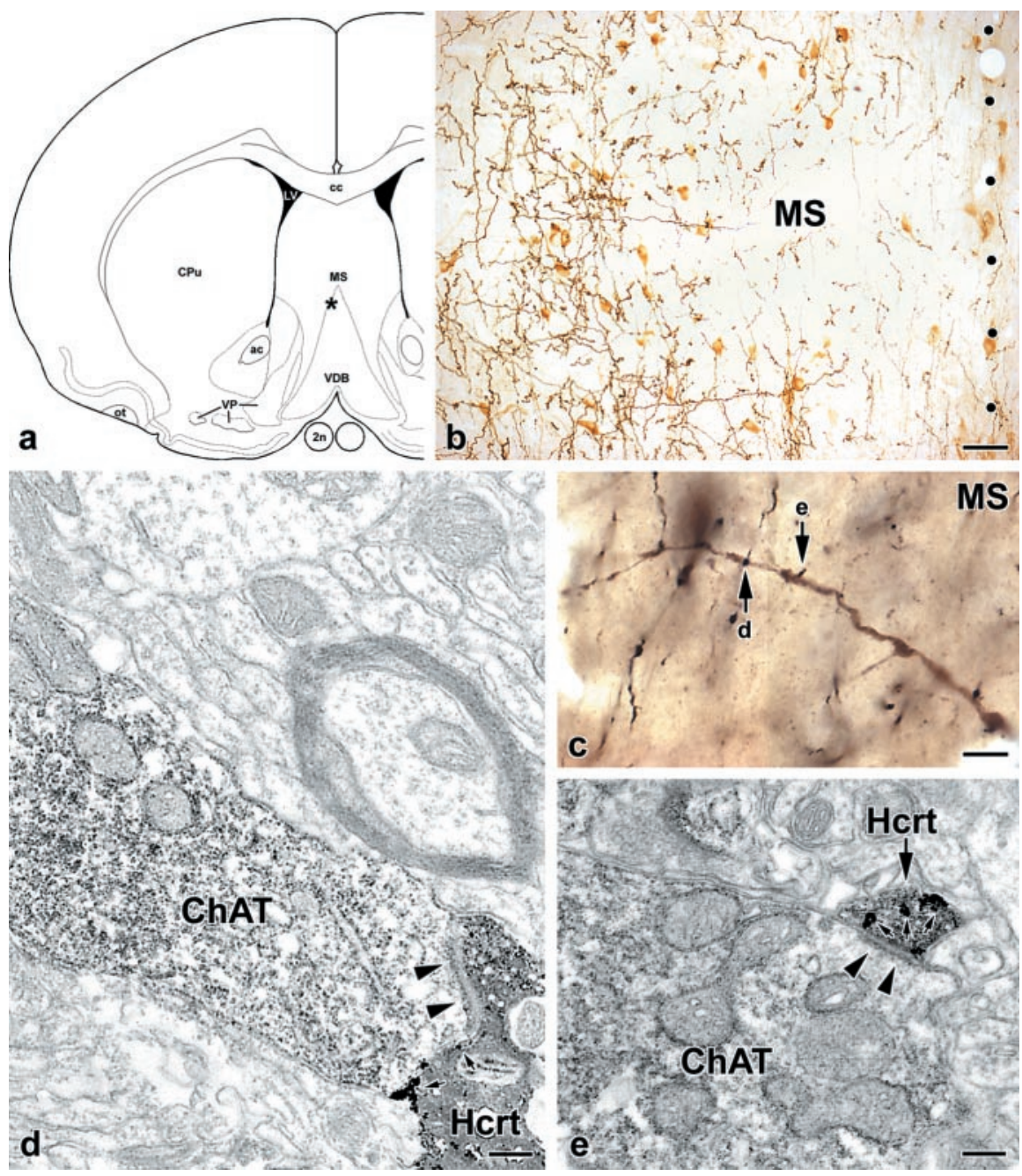

Figure 4. Ultrastructural evidence for the existence of asymmetric synaptic contacts between Hcrt-ir varicosities and choline acetyltransferase-positive septohippocampal neurons. $a$, In this schematic drawing, the asterisk indicates the location of the analyzed cholinergic dendrite shown in c. 2n, Optic nerve; ac, anterior commissure; cc, corpus callosum; CPu, caudate-putamen; LV, lateral ventricle; MS, medial septum; ot, olfactory tract; VDB, vertical limb of the diagonal band; VP, ventral pallidum. $b$, Low-power photomicrograph, taken from a double-immunostained coronal section of the medial septum, demonstrates the area marked by the asterisk in $a$. Cholinergic neuronal profiles are embedded in a rich network of Hcrt axons. Dots represent the midline. Scale bar, $40 \mu \mathrm{m}$. c, High-power photomicrograph, taken from a resin-embedded coronal section, that documents the light microscopic appearance of a cholinergic dendrite, labeled with DAB, contacted by several Hcrt-positive boutons, labeled with the particulate silver-enhanced peroxidase, in the medial septum. The arrows $(d, e)$ point to putative axodendritic contact sites that are demonstrated in the electron micrograph panels, $d$ and $e$, respectively. Scale bar, $8 \mu \mathrm{m}$. $d, e$, High-magnification electron micrographs reveal that the Hcrt boutons (Hcrt) form asymmetric type synapses (arrowheads) with the cholinergic dendrite (ChAT). Small arrows point to silver-gold granules in Hcrt-positive profiles. Scale bars, $200 \mathrm{~nm}$.

Keele et al., 1997). Moreover, the calculated reversal potential is predicted to shift to more depolarizing potentials as internal $\mathrm{Ca}^{2+}$ levels rise in the presence of Hcrt (Keele et al., 1997). For an accurate measurement of the reversal potential of the $\mathrm{Na}^{+}-\mathrm{Ca}^{2+}$ exchanger, the precise values for external sodium and calcium and internal sodium and calcium are needed (Ehara et al., 1989). Under our experimental conditions, in the presence of an agonist, internal $\mathrm{Ca}^{2+}$ levels are rising and not static and thus are hard to predict or measure (Keele et al., 1997). It should be mentioned that reversal potentials for responses mediated via nonselective cationic currents are readily obtained around -10 and $-30 \mathrm{mV}$, using internal and external solutions with $\mathrm{Na}^{+}$and $\mathrm{K}^{+}$ concentrations similar to those in the present study (Li et al., 2001). Thus, the lack of a reversal in the depolarizing range tested precludes involvement of a nonselective cationic conductance in these cells.

We next examined the relationship of Hcrt fibers with the cholinergic neurons of the MSDB using double-immunolabeling studies at the light and electron microscopic levels.

\section{Hcrt-immunoreactive boutons synapse with choline acetyltransferase- containing neurons in the MSDB}

The Hcrt-ir axons in the MSDB were typically thin, with frequent large varicosities (1.5-2 $\mu \mathrm{m}$ in diameter) and short intervaricose segments. These Hcrt fibers were concentrated mainly in the medial septum-lateral septum border zone and along the boundaries of the vertical limb of the diagonal band, where most of the cholinergic cells reside (Fig. 4a,b). ChAT-ir neurons were embedded in this network of Hcrt axons, and several close associations were encountered with both cell bodies and dendrites (Fig. 4b,c). During the quantitative light microscopic analysis, at least $70 \%$ of cholinergic neurons were found to form apparent contacts with at least one Hcrt-ir bouton on their perikarya or proximal dendrites, or both, in the MSDB. Furthermore, the electron microscopic observations provided ultrastructural evidence that Hcrt boutons establish synaptic contacts with ChAT-positive neurons. From the three animals, 10 individual Hcrt-ir varicosities closely associated to cholinergic profiles were randomly selected for ultrastructural analysis. Six varicosities were confirmed to form synapses with proximal or distal cholinergic dendrites. Four selected varicosities were located adjacent to ChAT-positive cell bodies, and two of them were confirmed to establish synapses with those cell bodies. All synapses were of the asymmetric type with prominent postsynaptic densities, suggesting that the Hcrt input exerts excitatory influence on ChAT-ir neurons. Figure 4 demonstrates the correlated light and electron microscopic analysis of two axodendritic synapses between Hcrt-ir varicosities and a cholinergic dendrite in the MSDB.

\section{Discussion}

The chief findings of the present study are as follows. (1) Most septohippocampal cholinergic neurons are strongly activated by exogenous Hcrt. (2) The excitatory effects of Hcrt are mediated via two mechanisms: suppression of a $\mathrm{K}^{+}$current, presumably an inward rectifier, and activation of a $\mathrm{Na}^{+}-\mathrm{Ca}^{2+}$ exchanger. (3) Septohippocampal cholinergic neurons are synaptically innervated by Hcrt-containing boutons. These results, in conjunction with our previous findings on septohippocampal GABAergic neurons, suggest that Hcrt release within the MSDB will produce a dramatic activation of its two major neuronal subpopulations 
that project to the hippocampus. The implications of these findings for hippocampal arousal, which itself is only sparsely innervated by Hcrt fibers, are discussed in light of the proposed role of Hcrt in maintaining wakefulness.

\section{Hcrt excites septohippocampal cholinergic neurons via a direct postsynaptic mechanism}

In the present study Hcrt excited 90\% of septohippocampal cholinergic neurons in a reversible, reproducible, and concentrationdependent manner. The Hcrt effect persisted in the presence of TTX, in $\mathrm{Ca}^{2+}$-free-high- $\mathrm{Mg}^{2+} \mathrm{ACSF}$, and in solutions containing ionotropic glutamate and GABA receptor antagonists, suggesting a direct postsynaptic action. The similar $\mathrm{EC}_{50}$ values for Hcrt1 and Hcrt2 peptides are consistent with the involvement of Hcrt-R2 (Sakurai et al., 1998; Eriksson et al., 2001; Burdakov et al., 2003; Lambe and Aghajanian, 2003) and the abundance of Hcrt-R2 message in the MSDB (see Introduction).

The $\mathrm{EC}_{50}$ values obtained in the present study are higher than those reported for the cortical glutamate and arcuate GABAergic neurons (Brown et al., 2002; Burdakov et al., 2003; Lambe and Aghajanian, 2003) but similar to those reported for the raphe serotonergic and septohippocampal GABAergic neurons (Liu et al., 2002; Wu et al., 2002). Studies on tegmental (Burlet et al., 2002) and preoptic (Eggermann et al., 2001) cholinergic neurons did not report the $\mathrm{EC}_{50}$ values for Hcrt. Whether these differences in $\mathrm{EC}_{50}$ values of Hcrt are caused by regional variations in the destruction of the Hcrt peptides by local peptidases or other factors remains unknown.

\section{Dual ionic mechanisms underlie the excitatory effects of Hcrt on septohippocampal cholinergic neurons}

Similar to the GABAergic arcuate (Burdakov et al., 2003), histamine tuberomammillary (Eriksson et al., 2001), and septohippocampal GABAergic neurons (Wu et al., 2002), Hcrt effects on septohippocampal cholinergic neurons involve activation of the $\mathrm{Na}^{+}-\mathrm{Ca}^{2+}$ exchanger. Unlike these neurons, however, the effects of Hcrt on septohippocampal cholinergic neurons also involve reduction of $\mathrm{K}^{+}$current, presumably an inward rectifier. This is supported by the observed effects of external $\mathrm{BaCl}_{2}$ and of replacing internal $\mathrm{K}^{+}$with $\mathrm{Cs}^{+}$, both of which reduced the Hcrtinduced inward current at $-65 \mathrm{mV}$ and altered $I-V$ relationships in a manner that suggested involvement of a $\mathrm{K}^{+}$as well as an additional conductance. That the additional conductance is $\mathrm{Na}^{+}$ dependent was concluded on the basis of the finding that Hcrt responses were reduced in low $\mathrm{Na}^{+}$-containing ACSF. Involvement of dual ionic mechanisms was further indicated by the fact that the effects of external $\mathrm{BaCl}_{2}$ and $\mathrm{Na}^{+}$replacement were additive.

The involvement of a $\mathrm{Na}^{+}-\mathrm{Ca}^{2+}$ exchanger and not a nonspecific cationic conductance was indicated by the following findings. (1) the Hcrt-induced inward current was reversibly reduced in $\mathrm{Li}^{+}$ACSF and enhanced in low $\mathrm{Ca}^{2+}$ ACSF. (2) Hcrt did not induce an inward current in cells recorded with internal solutions containing high concentrations of the rapidly acting calcium buffer, BAPTA. (3) Hcrt responses were reduced by external $\mathrm{Ni}^{2+}$, a nonselective blocker of the $\mathrm{Na}^{+}-\mathrm{Ca}^{2+}$ exchanger. (4) Low concentrations of KB-R7943, a blocker of the $\mathrm{Na}^{+}-\mathrm{Ca}^{2+}$ exchanger, blocked Hcrt-induced activation of septohippocampal cholinergic neurons. (5) The Hcrt current did not reverse at the expected reversal for a nonspecific cationic conductance.

Similar to the $\mathrm{Na}^{+}-\mathrm{Ca}^{2+}$ exchanger, the internal $\mathrm{Ca}^{2+}$ activated nonselective cationic current, CAN current, is also sensitive to internal BAPTA. Unlike the $\mathrm{Na}^{+}-\mathrm{Ca}^{2+}$ exchanger, how- ever, nonselective cationic channels as well as the CAN channels are permeable to $\mathrm{Li}^{+}$(Yellen, 1982; Kimura et al., 1987; Crepel et al., 1994; Cho et al., 2003). CAN channels are also permeable to Tris, and in the present study the Hcrt-induced inward current was significantly reduced in Tris ACSF (Partridge and Swandulla, 1988). Thus, our data do not support a major involvement of nonselective cationic currents or CAN currents in mediating the Hcrt response, although such mechanisms may be involved in the small minority of neurons that showed a clear-cut increase in input conductance near resting potentials.

In contrast, multiple lines of evidence support the involvement of the $\mathrm{Na}^{+}-\mathrm{Ca}^{2+}$ exchanger in the vast majority of neurons. Although it can be argued that KB-R7943, especially at higher concentrations, can affect other cellular processes in addition to the $\mathrm{Na}^{+}-\mathrm{Ca}^{2+}$ exchanger, the effects of external $\mathrm{Li}^{+}$and BAPTA support involvement of the $\mathrm{Na}^{+}-\mathrm{Ca}^{2+}$ exchanger rather than the cationic currents. It should also be mentioned that in the present study we used KB-R7943 at one-fourth the concentration that has typically been used to support involvement of the $\mathrm{Na}^{+}$ $\mathrm{Ca}^{2+}$ exchanger (Eriksson et al., 2001; Burdakov et al., 2003).

\section{Hcrt innervation of septohippocampal cholinergic neurons}

Physiological significance for the above reported actions of Hcrt is supported by our double-immunolabeling studies that were performed at light and electron microscopic levels. In these anatomical studies we have demonstrated the presence of asymmetric synaptic connections with prominent postsynaptic densities between Hcrt-containing fibers and septohippocampal cholinergic neurons. Thus far, synaptic innervation by Hcrt-containing fibers has been demonstrated only for the norepinephrinecontaining neurons of the locus coeruleus (Horvath et al., 1999b) and the NPY-containing cell bodies of the arcuate nucleus (Horvath et al., 1999a). Thus, the present study provides the first definitive evidence for synaptic innervation of cholinergic neurons by Hcrt fibers in the brain. Excitatory effects of Hcrt on cholinergic neurons of the magnocellular preoptic nucleus (Eggermann et al., 2001) and the laterodorsal tegmental nucleus (Burlet et al., 2002) have been reported, although the underlying ionic mechanisms and their dependence on sodium or potassium has not been studied. Thus, evidence for positive interactions between Hcrt and cholinergic neurons of the brain that are involved in the sleep-wake cycle continues to build.

\section{Implications for hippocampal arousal}

Hypocretins are strongly implicated both in narcolepsy and in normal sleep-wakefulness. Unmedicated narcoleptic humans are unable to maintain wakefulness, despite their ability to attempt volitional control of wake, and they also exhibit REM sleep disturbances. Hcrt levels fluctuate with the sleep-wake cycle. Of relevance to this study is the finding that Hcrt levels may be significantly higher in the rat basal forebrain during REM sleep as compared with slow wave sleep (Kiyashchenko et al., 2002). The resultant activation of septohippocampal cholinergic neurons during REM sleep could explain the high levels of hippocampal ACh release that occur during REM sleep (Marrosu et al., 1995) when aminergic inputs are quiescent.

Also, Hcrts, which are considered critical for the active maintenance of normal wakefulness, excite almost the entire septohippocampal nucleus by activating a vast majority of both septohippocampal cholinergic and GABAergic neurons (Wu et al., 2000). A profound excitation of the MSDB by Hcrts is likely to provide the hippocampus with a robust arousal stimulus via both the direct excitatory septohippocampal cholinergic pathway and the 
disinhibitory septohippocampal GABAergic pathway to offset any mounting sleep drives. The hippocampus itself is only sparsely innervated by Hcrt fibers (Peyron et al., 1998; Nambu et al., 1999). Interestingly, active waking per se is associated with higher hippocampal ACh levels in contrast to quiet waking (Marrosu et al., 1995). Consistent with the proposed arousal effects of Hcrts, infusion of Hcrt into the cholinergic basal forebrain increases wakefulness (Thakkar et al., 2001), and infusions of Hcrt directly into the MSDB enhance behavioral and electrical indices of arousal (Espana et al., 2001).

The profound excitatory actions of Hcrt on both the major neuronal septohippocampal populations are unlike that of other arousal-associated neurotransmitters, such as serotonin (Alreja, 1996; Liu and Alreja, 1997) and norepinephrine (Alreja and Liu, 1996), which excite only the septohippocampal GABAergic neurons. Muscarinic receptor activation, which produces robust theta, also excites only the septohippocampal GABAergic neurons and inhibits the septohippocampal cholinergic neurons (Wu et al., 2000). In light of the speculated role of the septohippocampal GABAergic neurons in sustaining the frequency of the theta rhythm and of cholinergic neurons in contributing to the power of the theta rhythm (Lee et al., 1994), it is likely that Hcrt actions in the septum would lead to higher-frequency theta activity and an amplitude higher than that observed with carbachol.

The ionic mechanisms underlying the actions of Hcrt in septohippocampal cholinergic neurons, which involve activation of the $\mathrm{Na}^{+}-\mathrm{Ca}^{2+}$ exchanger and inhibition of $\mathrm{K}^{+}$channels, presumably an inward rectifier, may also ensure that a robust wakefulness signal is transmitted to the hippocampus, because by closing inward rectifier $\mathrm{K}^{+}$channels, Hcrts will negate any ongoing inhibition of septohippocampal cholinergic neurons as can occur after activation of muscarinic or $\mathrm{GABA}_{\mathrm{B}}$ receptors. Recently, Hcrts were reported to inhibit neurotransmitter-activated inward rectifier $\mathrm{K}^{+}$channels (Hoang et al., 2003).

In conclusion, we provide evidence for Hcrt innervation and excitation of septohippocampal cholinergic neurons via a dual ionic mechanism. Thus, the present study may help understand how Hcrt actions on basal forebrain cholinergic neurons might regulate arousal states.

\section{References}

Alreja M (1996) Excitatory actions of serotonin on GABAergic neurons of the medial septum and diagonal band of Broca. Synapse 22:15-27.

Alreja M, Liu W (1996) Noradrenaline induces IPSCs in rat medial septal/ diagonal band neurons: involvement of septohippocampal GABAergic neurons. J Physiol (Lond) 494:201-215.

Alreja M, Wu M, Liu W, Atkins JB, Leranth C, Shanabrough M (2000) Muscarinic tone sustains impulse flow in the septohippocampal GABA but not cholinergic pathway: implications for learning and memory. J Neurosci 20:8103-8110.

Brown RE, Sergeeva OA, Eriksson KS, Haas HL (2002) Convergent excitation of dorsal raphe serotonin neurons by multiple arousal systems (orexin/hypocretin, histamine and noradrenaline). J Neurosci 22:8850-8859.

Burdakov D, Liss B, Ashcroft FM (2003) Orexin excites GABAergic neurons of the arcuate nucleus by activating the sodium-calcium exchanger. J Neurosci 23:4951-4957.

Burlet S, Tyler CJ, Leonard CS (2002) Direct and indirect excitation of laterodorsal tegmental neurons by hypocretin/orexin peptides: implications for wakefulness and narcolepsy. J Neurosci 22:2862-2872.

Chemelli RM, Willie JT, Sinton CM, Elmquist JK, Scammell T, Lee C, Richardson JA, Williams SC, Xiong Y, Kisanuki Y, Fitch TE, Nakazato M, Hammer RE, Saper CB, Yanagisawa M (1999) Narcolepsy in orexin knockout mice: molecular genetics of sleep regulation. Cell 98:437-451.

Chemelli RM, Sinton CM, Yanagisawa M (2000) Polysomnographic characterization of orexin-2 receptor knockout mice. Sleep 23:A296-A297.
Cho H, Kim MS, Shim WS, Yang YD, Koo J, Oh U (2003) Calcium-activated cationic channel in rat sensory neurons. Eur J Neurosci 17:2630-2638.

Cluderay JE, Harrison DC, Hervieu GJ (2002) Protein distribution of the orexin-2 receptor in the rat central nervous system. Regul Pept 104:131-144.

Crepel V, Aniksztejn L, Ben-Ari Y, Hammond C (1994) Glutamate metabotropic receptors increase a $\mathrm{Ca}(2+)$-activated nonspecific cationic current in CA1 hippocampal neurons. J Neurophysiol 72:1561-1569.

de Lecea L, Kilduff TS, Peyron C, Gao X, Foye PE, Danielson PE, Fukuhara C, Battenberg EL, Gautvik VT, Bartlett II FS, Frankel WN, van den Pol AN, Bloom FE, Gautvik KM, Sutcliffe JG (1998) The hypocretins: hypothalamus-specific peptides with neuroexcitatory activity. Proc Natl Acad Sci USA 95:322-327.

de Lecea L, Sutcliffe JG, Fabre V (2002) Hypocretins/orexins as integrators of physiological information: lessons from mutant animals. Neuropeptides 36:85-95.

Eggermann E, Serafin M, Bayer L, Machard D, Saint-Mleux B, Jones BE, Muhlethaler M (2001) Orexins/hypocretins excite basal forebrain cholinergic neurones. Neuroscience 108:177-181.

Ehara T, Matsuoka S, Noma A (1989) Measurement of reversal potential of $\mathrm{Na}^{+}-\mathrm{Ca}^{2+}$ exchange current in single guinea-pig ventricular cells. J Physiol (Lond) 410:227-249.

Eriksson KS, Sergeeva O, Brown RE, Haas HL (2001) Orexin/hypocretin excites the histaminergic neurons of the tuberomammillary nucleus. J Neurosci 21:9273-9279.

Espana RA, Baldo BA, Kelley AE, Berridge CW (2001) Wake-promoting and sleep-suppressing actions of hypocretin (orexin): basal forebrain sites of action. Neuroscience 106:699-715.

Farkas RH, Chien PY, Nakajima S, Nakajima Y (1996) Properties of a slow nonselective cation conductance modulated by neurotensin and other neurotransmitters in midbrain dopaminergic neurons. J Neurophysiol 76:1968-1981.

Gorelova N, Reiner PB (1996) Role of the afterhyperpolarization in control of discharge properties of septal cholinergic neurons in vitro. J Neurophysiol 75:695-706.

Griffith WH, Matthews RT (1986) Electrophysiology of AChE-positive neurons in basal forebrain slices. Neurosci Lett 71:169-174.

Haj-Dahmane S, Andrade R (1996) Muscarinic activation of a voltagedependent cation nonselective current in rat association cortex. J Neurosci 16:3848-3861.

Hajszan T, Zaborszky L (2002) Direct catecholaminergic-cholinergic interactions in the basal forebrain. III. Adrenergic innervation of choline acetyltransferase-containing neurons in the rat. J Comp Neurol 449:141-157.

Hara J, Beuckmann computed tomography, Nambu T, Willie JT, Chemelli RM, Sinton CM, Sugiyama F, Yagami K, Goto K, Yanagisawa M, Sakurai $\mathrm{T}$ (2001) Genetic ablation of orexin neurons in mice results in narcolepsy, hypophagia, and obesity. Neuron 30:345-354.

Hartig W, Seeger J, Naumann T, Brauer K, Bruckner G (1998) Selective in vivo fluorescence labeling of cholinergic neurons containing p75(NTR) in the rat basal forebrain. Brain Res 808:155-165.

Hervieu GJ, Cluderay JE, Harrison DC, Roberts JC, Leslie RA (2001) Gene expression and protein distribution of the orexin-1 receptor in the rat brain and spinal cord. Neuroscience 103:777-797.

Hoang QV, Bajic D, Yanagisawa M, Nakajima S, Nakajima Y (2003) Orexin (hypocretin) effects on GIRK channels. J Neurophysiol 90:693-702.

Horvath TL, Diano S, van den Pol AN (1999a) Synaptic interaction between hypocretin (orexin) and neuropeptide $\mathrm{Y}$ cells in the rodent and primate hypothalamus: a novel circuit implicated in metabolic and endocrine regulations. J Neurosci 19:1072-1087.

Horvath TL, Peyron C, Diano S, Ivanov A, Aston-Jones G, Kilduff TS, van Den Pol AN (1999b) Hypocretin (orexin) activation and synaptic innervation of the locus coeruleus noradrenergic system. J Comp Neurol 415:145-159.

Ivanov A, Aston-Jones G (2000) Hypocretin/orexin depolarizes and decreases potassium conductance in locus coeruleus neurons. NeuroReport 11:1755-1758.

Keele NB, Arvanov VL, Shinnick-Gallagher P (1997) Quisqualate-preferring metabotropic glutamate receptor activates $\mathrm{Na}(+)-\mathrm{Ca}^{2+}$ exchange in rat basolateral amygdala neurones. J Physiol (Lond) 499:87-104.

Kilduff TS, Peyron C (2000) The hypocretin/orexin ligand-receptor system: implications for sleep and sleep disorders. Trends Neurosci 23:359-365.

Kimura J, Miyamae S, Noma A (1987) Identification of sodium-calcium 
exchange current in single ventricular cells of guinea-pig. J Physiol (Lond) 384:199-222.

Kiyashchenko LI, Mileykovskiy BY, Maidment N, Lam HA, Wu MF, John J, Peever J, Siegel JM (2002) Release of hypocretin (orexin) during waking and sleep states. J Neurosci 22:5282-5286.

Korotkova TM, Sergeeva OA, Eriksson KS, Haas HL, Brown RE (2003) Excitation of ventral tegmental area dopaminergic and nondopaminergic neurons by orexins/hypocretins. J Neurosci 23:7-11.

Kushida CA, Baker TL, Dement WC (1985) Electroencephalographic correlates of cataplectic attacks in narcoleptic canines. Electroencephalogr Clin Neurophysiol 61:61-70.

Lambe EK, Aghajanian GK (2003) Hypocretin (orexin) induces calcium transients in single spines postsynaptic to identified thalamocortical boutons in prefrontal slice. Neuron 40:139-150.

Lee K, Boden PR (1997) Characterization of the inward current induced by metabotropic glutamate receptor stimulation in rat ventromedial hypothalamic neurones. J Physiol 504:649-663.

Lee MG, Chrobak JJ, Sik A, Wiley RG, Buzsaki G (1994) Hippocampal theta activity following selective lesion of the septal cholinergic system. Neuroscience 62:1033-1047.

Li AH, Yeh TH, Tan PP, Hwang HM, Wang HL (2001) Neurotensin excitation of serotonergic neurons in the rat nucleus raphe magnus: ionic and molecular mechanisms. Neuropharmacology 40:1073-1083.

Lin L, Faraco J, Li R, Kadotani H, Rogers W, Lin X, Qiu X, de Jong PJ, Nishino S, Mignot E (1999) The sleep disorder canine narcolepsy is caused by a mutation in the hypocretin (orexin) receptor 2 gene. Cell 98:365-376.

Liposits Z, Setalo G, Flerko B (1984) Application of the silver-gold intensified 3,3'-diaminobenzidine chromogen to the light and electron microscopic detection of the luteinizing hormone-releasing hormone system of the rat brain. Neuroscience 13:513-525.

Liu RJ, van den Pol AN, Aghajanian GK (2002) Hypocretins (orexins) regulate serotonin neurons in the dorsal raphe nucleus by excitatory direct and inhibitory indirect actions. J Neurosci 22:9453-9464.

Liu W, Alreja M (1997) Atypical antipsychotics block the excitatory effects of serotonin in septohippocampal neurons in the rat. Neuroscience 79:369-382.

Marcus JN, Aschkenasi CJ, Lee CE, Chemelli RM, Saper CB, Yanagisawa M, Elmquist JK (2001) Differential expression of orexin receptors 1 and 2 in the rat brain. J Comp Neurol 435:6-25.

Markram H, Segal M (1990) Electrophysiological characteristics of cholinergic and non-cholinergic neurons in the rat medial septum-diagonal band complex. Brain Res 513:171-174.

Marrosu F, Portas C, Mascia MS, Casu MA, Fa M, Giagheddu M, Imperato A, Gessa GL (1995) Microdialysis measurement of cortical and hippocampal acetylcholine release during sleep-wake cycle in freely moving cats. Brain Res 671:329-332.

Mignot E, Taheri S, Nishino S (2002) Sleeping with the hypothalamus: emerging therapeutic targets for sleep disorders. Nat Neurosci [Suppl] 5:1071-1075.

Montplaisir J, Petit D, Gauthier S, Gaudreau H, Decary A (1998) Sleep disturbances and EEG slowing in Alzheimer's disease. Sleep Res Online $1: 147-151$.

Mubagwa K, Stengl M, Flameng W (1997) Extracellular divalent cations block a cation non-selective conductance unrelated to calcium channels in rat cardiac muscle. J Physiol (Lond) 502:235-247.

Nambu T, Sakurai T, Mizukami K, Hosoya Y, Yanagisawa M, Goto K (1999) Distribution of orexin neurons in the adult rat brain. Brain Res 827:243-260.

Parsons JE, Wallis RA, Panizzon KL, Wasterlain CG (1992) Low sodium injury in the hippocampal slice is mediated through NMDA receptors. Brain Res 595:141-144.

Partridge LD, Swandulla D (1988) Calcium-activated non-specific cation channels. Trends Neurosci 11:69-72.

Peyron C, Tighe DK, van den Pol AN, de Lecea L, Heller HC, Sutcliffe JG, Kilduff TS (1998) Neurons containing hypocretin (orexin) project to multiple neuronal systems. J Neurosci 18:9996-10015.

Peyron C, Faraco J, Rogers W, Ripley B, Overeem S, Charnay Y, Nevsimalova S, Aldrich M, Reynolds D, Albin R, Li R, Hungs M, Pedrazzoli M, Padigaru M, Kucherlapati M, Fan J, Maki R, Lammers GJ, Bouras C, Kucherlapati R, Nishino S, Mignot E (2000) A mutation in a case of early onset narcolepsy and a generalized absence of hypocretin peptides in human narcoleptic brains. Nat Med 6:991-997.

Sakurai T, Amemiya A, Ishii M, Matsuzaki I, Chemelli RM, Tanaka H, Williams SC, Richardson JA, Kozlowski GP, Wilson S, Arch JR, Buckingham RE, Haynes AC, Carr SA, Annan RS, McNulty DE, Liu WS, Terrett JA, Elshourbagy NA, Bergsma DJ, Yanagisawa M (1998) Orexins and orexin receptors: a family of hypothalamic neuropeptides and $G$ proteincoupled receptors that regulate feeding behavior. Cell 92:573-585.

Scammell TE (2003) The neurobiology, diagnosis, and treatment of narcolepsy. Ann Neurol 53:154-166.

Shao XM, Feldman JL (2000) Acetylcholine modulates respiratory pattern: effects mediated by M3-like receptors in pre-Botzinger complex inspiratory neurons. J Neurophysiol 83:1243-1252.

Shen KZ, North RA (1992) Muscarine increases cation conductance and decreases potassium conductance in rat locus coeruleus neurones. J Physiol (Lond) 1992:471-485.

Siegel JM, Nienhuis R, Gulyani S, Ouyang S, Wu MF, Mignot E, Switzer RC, McMurry G, Cornford M (1999) Neuronal degeneration in canine narcolepsy. J Neurosci 19:248-257.

Thakkar MM, Ramesh V, Strecker RE, McCarley RW (2001) Microdialysis perfusion of orexin-A in the basal forebrain increases wakefulness in freely behaving rats. Arch Ital Biol 139:313-328.

Thannickal TC, Moore RY, Nienhuis R, Ramanathan L, Gulyani S, Aldrich M, Cornford M, Siegel JM (2000) Reduced number of hypocretin neurons in human narcolepsy. Neuron 27:469-474.

Trivedi P, Yu H, MacNeil DJ, Van der Ploeg LH, Guan XM (1998) Distribution of orexin receptor mRNA in the rat brain [Erratum (1999) 442: 122]. FEBS Lett 438:71-75.

Tsien RY (1980) New calcium indicators and buffers with high selectivity against magnesium and protons: design, synthesis, and properties of prototype structures. Biochemistry 19:2396-2404.

van den Pol AN, Gao XB, Obrietan K, Kilduff TS, Belousov AB (1998) Presynaptic and postsynaptic actions and modulation of neuroendocrine neurons by a new hypothalamic peptide, hypocretin/orexin. J Neurosci 18:7962-7971.

van den Top M, Nolan MF, Lee K, Richardson PJ, Buijs RM, Davies CH, Spanswick D (2003) Orexins induce increased excitability and synchronisation of rat sympathetic preganglionic neurones. J Physiol (Lond) 549:809-821.

Vanderwolf CH (1969) Hippocampal electrical activity and voluntary movement in the rat. Electroencephalogr Clin Neurophysiol 26:407-418.

Vitiello MV, Prinz PN (1989) Alzheimer's disease. Sleep and sleep/wake patterns. Clin Geriatr Med 5:289-299.

Willie JT, Chemelli RM, Sinton CM, Tokita S, Williams SC, Kisanuki YY, Marcus JN, Lee C, Elmquist JK, Kohlmeier KA, Leonard CS, Richardson JA, Hammer RE, Yanagisawa M (2003) Distinct narcolepsy syndromes in orexin receptor-2 and orexin null mice. Molecular genetic dissection of non-REM and REM sleep regulatory processes. Neuron 38:715-730.

Winson J (1976) Hippocampal theta rhythm. II. Depth profiles in the freely moving rabbit. Brain Res 103:71-79.

Wu M, Shanabrough M, Leranth C, Alreja M (2000) Cholinergic excitation of septohippocampal GABA but not cholinergic neurons: implications for learning and memory. J Neurosci 20:3900-3908.

Wu M, Zhang Z, Leranth C, Xu C, van den Pol AN, Alreja M (2002) Hypocretin increases impulse flow in the septohippocampal GABAergic pathway: implications for arousal via a mechanism of hippocampal disinhibition. J Neurosci 22:7754-7765.

Wu M, Hajszan T, Leranth C, Alreja M (2003a) Nicotine recruits a local glutamatergic circuit to excite septohippocampal GABAergic neurons. Eur J Neurosci 18:1155-1168.

Wu M, Newton SS, Atkins JB, Xu C, Duman RS, Alreja M (2003b) Acetylcholinesterase inhibitors activate septohippocampal GABAergic neurons via muscarinic but not nicotinic receptors. J Pharmacol Exp Ther 307:535-543.

Yang B, Ferguson AV (2002) Orexin-A depolarizes dissociated rat area postrema neurons through activation of a nonselective cationic conductance. J Neurosci 22:6303-6308.

Yellen G (1982) Single $\mathrm{Ca}^{2+}$-activated nonselective cation channels in neuroblastoma. Nature 296:357-359. 